University of Nebraska - Lincoln

DigitalCommons@University of Nebraska - Lincoln

USGS Staff -- Published Research

US Geological Survey

2010

Development and application of a pollen-based paleohydrologic reconstruction from the Lower Roanoke River Basin, North Carolina, USA

Debra Willard

US Geological Survey

Christopher Bernhardt

US Geological Survey

Roger Brown

Columbus State University

Bryan Landacre

US Geological Survey

Philip A. Townsend

University of Wisconsin-Madison, ptownsend@wisc.edu

Follow this and additional works at: http:// digitalcommons.unl.edu/usgsstaffpub

Part of the Geology Commons, Oceanography and Atmospheric Sciences and Meteorology Commons, Other Earth Sciences Commons, and the Other Environmental Sciences Commons

Willard, Debra; Bernhardt, Christopher; Brown, Roger; Landacre, Bryan; and Townsend, Philip A., "Development and application of a pollen-based paleohydrologic reconstruction from the Lower Roanoke River Basin, North Carolina, USA" (2010). USGS Staff -Published Research. 896.

http://digitalcommons.unl.edu/usgsstaffpub/896

This Article is brought to you for free and open access by the US Geological Survey at DigitalCommons@University of Nebraska - Lincoln. It has been accepted for inclusion in USGS Staff -- Published Research by an authorized administrator of DigitalCommons@University of Nebraska - Lincoln. 


\title{
Development and application of a pollen-based paleohydrologic reconstruction from the Lower Roanoke River Basin, North Carolina, USA
}

\author{
Debra Willard,' Christopher Bernhardt,, ${ }^{1,2}$ Roger Brown, ${ }^{3}$ \\ Bryan Landacre' and Philip Townsend ${ }^{4}$
}

\begin{abstract}
We used pollen assemblages to reconstruct late-Holocene paleohydrologic patterns in floodplain deposits from the lower Roanoke River basin (North Carolina, southeastern USA). Using 120 surface samples from 38 transects, we documented statistical relationships between pollen assemblages, vegetation, and landforms. Backswamp pollen assemblages (long hydroperiods) are dominated by Nyssa (tupelo) and Taxodium (cypress) and have high pollen concentrations. Sediments from elevated levees and seasonally flooded forests (shorter hydroperiods) are characterized by dominant Pinus (pine) pollen, variable abundance of hardwood taxa, and low pollen concentrations. We apply the calibration data set to interpret past vegetation and paleohydrology. Pollen from a radiocarbon-dated sediment core collected in a tupelo-cypress backswamp indicates centennial-scale fluctuations in forest composition during the last 2400 years. Backswamp vegetation has occupied the site since land clearance began $\sim 300$ years ago. Recent dam emplacement affected sedimentation rates, but vegetation changes are small compared with those caused by pre-Colonial climate variability. The occurrence of wetter conditions from 2200 to $1800 \mathrm{cal}$.yr BP, I 100 to $750 \mathrm{cal}$.yr BP, and 400 to $250 \mathrm{cal}$.yr BP may indicate changes in cyclonic circulation patterns related to shifts in the position of the Bermuda High and jet stream.
\end{abstract}

\section{Keywords}

Atlantic Coastal Plain, floodplains, hydroperiod, paleohydrology, pollen, vegetation

\section{Introduction}

Riparian forests of the Atlantic Coastal Plain of North America contain diverse wetland assemblages that include tidal marshes, freshwater marshes, southern deepwater swamps, and bottomland hardwood forests. These wetlands provide critical habitats for plant and animal communities and play an important role in maintaining water quality by trapping sediment, contaminants, and nutrients (Hupp, 2000). Extensive tracts of these wetlands have been lost since Colonial land clearance in the eighteenth and nineteenth centuries (Mitsch and Gosselink, 2000) and twentieth-century construction of dams that altered seasonal discharge rates and patterns, sedimentation, and forest composition (Graf, 2006; Pearsall et al., 2005). The lower Roanoke River (LRR), located on the Atlantic Coastal Plain of North Carolina (Figure 1), is a large, minimally disturbed bottomland forest (Townsend, 2001) that provides a natural laboratory to examine wetland response to hydrologic and environmental changes associated with dam operations, land-use changes, and climate variability over a range of temporal and spatial scales.

Hydrology is the primary control on the composition and distribution of floodplain vegetation in the Atlantic Coastal Plain (Townsend, 2001). Because dam operations change the timing and magnitude of peak flows, they often are considered to have much greater impacts on discharge and, by extension, wetland hydrology than climate change and variability (Graf, 1999; Townsend and Foster, 2002). To evaluate such hypotheses, we must consider long hydrologic records that capture the variability associated with climate processes operating on multidecadal timescales. The longest instrumental records of river discharge and precipitation extend only to the early twentieth century and cannot address questions either on hydrologic variability over long temporal scales or hydrologic patterns of the floodplain before it was substantially altered by Colonial land clearance. Hydrologic proxies preserved in sediments provide a means to compare the

\footnotetext{
'US Geological Survey, USA

${ }^{2}$ University of Pennsylvania, USA

${ }^{3}$ Columbus State University, USA

${ }^{4}$ University of Wisconsin, USA
}

Received 23 November 2009; revised manuscript accepted I2 June 2010

\section{Corresponding author:}

Debra Willard, U.S. Geological Survey, Reston VA, USA.

Email: dwillard@usgs.gov 


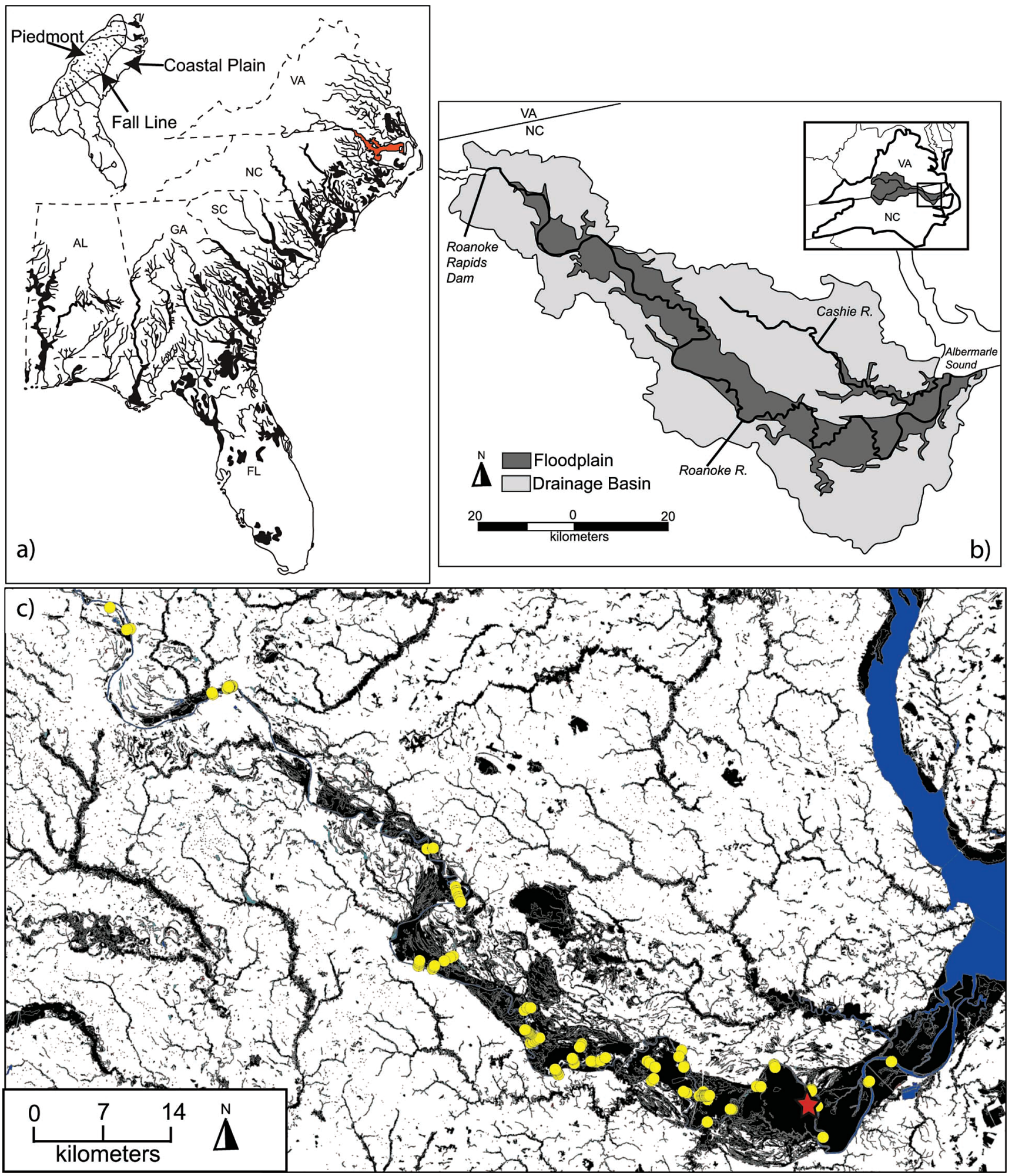

Figure I. (a) Distribution of rivers in Coastal Plains of southeastern USA. Roanoke River is highlighted in red. Potential extent of bottomland hardwood forests is shown along major streams (modified from Putnam et al., 1960). (b) Distribution of lower Roanoke River (LRR) floodplain (dark gray shading) within LRR drainage basin (light gray shading), North Carolina. Inset map shows extent of entire Roanoke River watershed in Virginia and North Carolina. (c) Satellite image of LRR showing location of study transects. Yellow circles indicate location of surface samples, and the red star indicates the location of sediment Core 0I-I0-II-4

natural wetland hydrology with that of the modern system and to evaluate such questions.

Although many pollen-based reconstructions come from lake sediments (Delcourt and Delcourt, 1984; Watts, 1979, 1980; Watts et al., 1996; Whitehead, 1972; Whitmore et al., 2005), wetland sediments increasingly are being used for paleohydrologic studies
(Chmura et al., 2006; Cohen et al., 1999; Goman and Leigh, 2004; LaMoreaux et al., 2009; Pederson et al., 2005; Whitehead, 1972; Willard et al., 2006). Pollen assemblages preserved in wetland sediments typically contain a more localized pollen signature than those from lake sediments (Bunting et al., 1998), and thus reflect both regional climate and a strong overprint of local 
hydrologic fluctuations. In the Atlantic Coastal Plain, substantial differences in elevation and substrate exist along the length of the stream from the Fall Line to the river mouth as well as laterally from levee to backswamp. Such variability affects local hydroperiods (annual duration of inundation) and influences the amount of spatial heterogeneity within floodplain vegetation.

Here we evaluate the sensitivity of sedimentary pollen records to hydrologic variability in floodplain environments. We quantified pollen from surface samples and associated source plants and environments (hydroperiod, substrate, and elevation) from the LRR basin. Using this calibration data set, we examined lateHolocene vegetation and reconstructed hydroperiod from a sediment core collected in a tupelo-cypress backswamp in the lower reaches of the Roanoke River.

\section{Regional setting}

The Roanoke River is an alluvial river with its headwaters situated in the Blue Ridge Mountains of south-central Virginia, following a high topographic gradient from the Piedmont across the Fall Line, and flowing across the Atlantic Coastal Plain to its mouth at Albemarle Sound, North Carolina (Figure 1). The LRR basin is $>200 \mathrm{~km}$ long with an area of $\sim 9000 \mathrm{~km}^{2}$ (US Department of Health, Education, and Welfare, 1962). Its floodplain is 5-10 $\mathrm{km}$ wide and contains the largest remaining contiguous bottomland hardwood forest of the Atlantic Coastal Plain (Hupp, 2000). The present river flow and floodplain hydroperiod are regulated by a series of seven dams in the upper reaches of the river. Coastal Plain rivers are characterized by two distinct hydrological seasons, a low-flow summer season when stream flow is restricted to the river channel and a high-flow winter to spring season when large areas of the floodplain are inundated (Hupp, 2000; Townsend, 2001). The annual period of inundation in wetlands is referred to as the hydroperiod, which ranges from a few days on high-elevation sites such as levees to many months in low-elevation sites of deep swamps. The dynamic nature of this hydrologic regime results in significant erosion, transport, and deposition of sediment on the floodplain and a near constant state of sediment flux within the system. Coastal Plain floodplains have acted as sediment sinks during the late Holocene, and lateral accretion of sediment during flood events has influenced the structure of the floodplain environment, with coarse-grained sediments deposited on levees and finer-grained sediments deposited in backswamps distal to the stream. Hydrologic variation is enhanced by the presence of abandoned channels and other features that retain moisture differently than surrounding sediments. The hydrologic, topographic, and geomorphic diversity (substrate elevation, distance from river mouth, soil texture and organic matter content) inherent to Coastal Plain floodplains determines the structure of floodplain vegetation (Rice and Peet, 1997; Townsend, 2001).

Hydroperiod influences oxygen availability in soils, and species adaptability to anoxic stresses plays a large role in determining community composition across bottomland hydrologic gradients (Huffman and Forsythe, 1981; Wharton et al., 1982). On floodplains, a few centimeters difference in substrate elevation can significantly influence hydroperiod, resulting in altered community composition over a distance of meters. Coastal Plain floodplains may be described as a mosaic of backswamps, flats, and levees that generally reflect the underlying geomorphology of the area.

Forested peatlands, dominated by Nyssa biflora, Magnolia virginiana, and Persea palustris, are centered on organic soils on the lowest-elevation floodplains near the Roanoke River mouth (Townsend, 2001). Swamp forests, including backswamps of many Coastal Plain rivers, are dominated by Nyssa aquatica and Taxodium distichum and typically occur on organic-rich, mineral substrates with long hydroperiods (annual flooding $>200$ days during wet years) in areas of very low topographic relief (Table 1) (Conner and Buford, 1998). Tupelo-cypress forests are inundated from the winter through summer seasons. Other canopy species in tupelo-cypress forests include Salix nigra, Acer rubrum, and Populus heterophylla. Along the margins of deepwater swamps, Quercus lyrata, Carya aquatica, and Ulmus americana may be common (Conner and Buford, 1998).

Wet bottomland hardwood (BHW) forests occur on transitional features between swamp forests and levees, and mesic BHW forests predominate on higher levees and ridges. Wet BHW forests are flooded for one to two months during the growing season and are characterized by a greater diversity of hardwood trees than occur in tupelo-cypress swamps. Common canopy species include Acer rubrum, Fraxinus pennsylvanica, Ulmus americana, Liquidambar stryaciflua, and Celtis laevigata (Townsend, 2001). Mesic BHW forests flood infrequently (1 week to 1 month during the growing season) and include species of Quercus and Carya as well as Pinus taeda in peripheral sites. Mesic Fagus and Quercus forests occur on dry sites with $<50$ days flooding during the wet years.

The humid temperate regional climate has mean annual temperatures of $15-16^{\circ} \mathrm{C}$ and precipitation of $1100-1300 \mathrm{~mm}$ from AD 1895 to 2007 (Southeast Regional Climate Center Historical Climate Summaries: http://www.sercc.com/climateinfo/historical/ historical.html; viewed 19 August 2009). Although winter temperatures in the region occasionally reach freezing, average winter temperatures $\left(5-7^{\circ} \mathrm{C}\right)$ are consistent with a warm, equable climate. Precipitation typically is highest in the summer (JJA) and lowest in the autumn (SON), and the seasonality of rainfall is influenced both by El Niño/Southern Oscillation (ENSO) cycles (Boyles et al., 2004) and the Bermuda High Index (BHI) and changes in strength of subtropical atmospheric circulation (Diem, 2006; Henderson and Vega, 1996).

\section{Methods}

\section{Study design and site characterization}

Thirty-eight transects were established from the levee into the backswamp along the length of the LRR (Figure 1). Transects were referenced by placing metal spikes into a mature trees, serving as monuments for present and future studies. Locations were recorded on maps and documented using a Global Positioning System (GPS) with horizontal accuracy of $\sim 3.5 \mathrm{~m}$. Elevations were recorded and corrected to NGVD 1929 datum (Hupp et al., 2009a). Transect lengths ranged from $100 \mathrm{~m}$ to $2 \mathrm{~km}$ with stops every $50-100 \mathrm{~m}$. Tree tags were affixed to witness trees at each stop, and the locations were noted using GPS. Each stop was assigned to a particular landform (levee, flat, backswamp, ridge, etc.), and precise locations and elevations were determined. Percent cover of canopy, subcanopy, shrub, and herbaceous layers were quantified at most stops on each transect using the North Carolina Vegetation Survey (NCVS) methodology described in Peet et al. (1998). This method locates standard $10 \mathrm{~m} \times 10 \mathrm{~m}$ quadrats at each stop to minimize within-plot environmental heterogeneity. Percent cover, defined as the percentage of ground 
Table I. Vegetation classes represented in Lower Roanoke River floodplain study. Hydroperiod tolerances are provided for vegetation classes rather than individual species. Median annual hydroperiods indicate the median number of days of inundation, but hydroperiods during extremely wet years determine floodplain forest composition by eliminating species that cannot tolerate longer than average flood regimes (Townsend, 200I). Median annual hydroperiods for forest classes were compiled from Townsend (200I). Post-dam hydroperiods for wet years represent hydroperiod ranges for sites included in study. Percent cover values for species in LRR sites are derived from measurements made using the North Carolina Vegetation Survey (NCVS) methodology (Peet et al., 1998). Elevations are corrected to NGVD 1929 datum

\begin{tabular}{|c|c|c|c|c|c|}
\hline Class name & Primary canopy species & $\begin{array}{l}\text { Vegetation class } \\
\text { median annual } \\
\text { hydroperiod }^{\mathrm{a}}\end{array}$ & $\begin{array}{l}\text { Hydroperiod, } \\
\text { post-dam, wet } \\
\text { years }{ }^{\mathrm{b}}\end{array}$ & $\begin{array}{l}\text { Percent } \\
\text { cover }\end{array}$ & $\begin{array}{l}\text { Elevation above } \\
\text { Roanoke River } \\
\text { surface }(\mathrm{cm})\end{array}$ \\
\hline \multirow{2}{*}{$\begin{array}{l}\text { Swamp forests } \\
\text { Tupelo-Cypress } \\
\text { backswamps }\end{array}$} & & $227-230$ & $200-350$ & & $0-50$ \\
\hline & $\begin{array}{l}\text { Nyssa aquatica } \\
\text { Taxodium distichum } \\
\text { Populus heterophylla }\end{array}$ & & & $\begin{array}{r}63-85 \\
4-18 \\
0.5-38\end{array}$ & \\
\hline Low ridges and flats & $\begin{array}{l}\text { Nyssa aquatica } \\
\text { Taxodium distichum } \\
\text { Populus heterophylla } \\
\text { Acer spp., Carya aquatica, Fraxinus } \\
\text { pennsylvanica, Platanus occidentalis, } \\
\text { Liquidambar styraciflua, Quercus spp. }\end{array}$ & $96-213$ & $130-300$ & $\begin{array}{l}\leq 38 \\
\leq 38 \\
\leq 63 \\
\leq 18 \text { each }\end{array}$ & $30-100$ \\
\hline \multicolumn{6}{|l|}{ Wet bottomland forests } \\
\hline Maple-Oak-Tupelo & $\begin{array}{l}\text { Acer rubrum } \\
\text { Fraxinus pennsylvanica } \\
\text { Nyssa aquatica } \\
\text { Ulmus americana } \\
\text { Populus heterophylla }\end{array}$ & 77 & $10-180$ & $\begin{array}{l}\leq 38 \\
\leq 63 \\
\leq 38 \\
\leq 38 \\
\leq 18\end{array}$ & $33-190$ \\
\hline Ash-Maple-Boxelder & $\begin{array}{l}\text { Fraxinus pennsylvanica } \\
\text { Acer rubrum, Acer negundo }\end{array}$ & 46 & $40-120$ & $\begin{array}{l}18-85 \\
\leq 18\end{array}$ & $100-190$ \\
\hline \multicolumn{6}{|l|}{ Mixed mesic hardwoods } \\
\hline High levee bottomlands & Acer spp., Celtis, Fraxinus, Platanus, Fagus & $<10$ & $<50$ & $18-63$ each & $>200$ \\
\hline Mixed mesic hardwoods & $\begin{array}{l}\text { Diverse assemblages including } \\
\text { Acer, Celtis, Carya, Fagus, Fraxinus, } \\
\text { Liquidambar, Populus, Quercus }\end{array}$ & $<10$ & $<50$ & 4-18 each & $133-397$ \\
\hline
\end{tabular}

a Median annual hydroperiods for vegetation classes were compiled from Townsend (200I).

${ }^{b}$ Post-dam, wet-year hydroperiods for sites in this study were derived from a model of potential flood inundation for the lower Roanoke River floodplain as described in Townsend and Walsh (1998).

surface obscured by the vertical projection of all aboveground parts of a given species onto the ground, was noted for each quadrat. The NCVS system uses a ten-point scale in which successively higher increments indicate approximate doubling of cover (Peet et al., 1998), and the sum of cover estimates across all species may exceed $100 \%$. These data ultimately were used to assign specific vegetation classes to observed forests at each stop (Table 1). Hydroperiod for each site was derived by integrating GIS coverages, Landsat Thematic Mapper time series, and synthetic aperture radar images into a model of potential flood inundation for the lower Roanoke River floodplain (Townsend and Walsh, 1998). Because annual flooding during wet years is the strongest predictor of spatial distribution of floodplain vegetation in the LRR (Townsend, 2001), we used that value for each site to reconstruct hydroperiod from surface pollen assemblages.

\section{Palynological sampling and analysis}

The upper $1 \mathrm{~cm}$ of sediment was collected using mini-cores in 50 $\mathrm{ml}$ centrifuge tubes after removal of plant litter. Sediment texture and color were described for each sample. Pollen was isolated from 120 sediment samples representing distinct vegetation types from 38 transects using standard palynological techniques outlined in Willard et al. (2003, 2005). Approximately 3-10 g of dry sediment was used for palynological analysis, depending on lithology. After drying and weighing samples, one Lycopodium marker tablet was added to each dried sample for eventual calculation of absolute pollen concentrations (Stockmarr, 1971). Samples were demineralized using $\mathrm{HCl}$ and $\mathrm{HF}$ before being acetolyzed (nine parts acetic anhydride:one part sulfuric acid) in a hot-water bath $\left(100^{\circ} \mathrm{C}\right)$ for $10 \mathrm{~min}$. After neutralization, they were treated with $10 \% \mathrm{KOH}$ in a hot-water bath for $15 \mathrm{~min}$. Neutralized samples were sieved with $10 \mu \mathrm{m}$ and $200 \mu \mathrm{m}$ sieves, and the 10-200 $\mu \mathrm{m}$ fraction was stained with Bismarck Brown, mixed with warm glycerin jelly, and mounted on microscope slides. Raw data and metadata for pollen samples are reposited in the North American Pollen Database (NAPD) at the World Data Center for Paleoclimatology in Boulder, Colorado, USA (http://www.ncdc.noaa.gov/ paleo/napd.html and in Supplementary Tables 1-5, available online). Pollen and spore identification (minimally 300 grains per sample) was based on reference collections of the US Geological Survey (Reston, Virginia).

Absolute pollen concentrations were calculated using the marker-grain method described by Benninghoff (1962). The number of Lycopodium spores in the marker tablets was determined by the manufacturer with a Coulter Counter following the 
procedures of Stockmarr (1973) as $10679 \pm 191$ : absolute pollen concentration was calculated using the formula (Maher, 1981):

$\begin{aligned} & \text { Pollen per gram } \\ & \text { dry sediment }=\end{aligned}$
$\begin{aligned} & \text { (Pollen grains counted/ } \\ & \text { markers counted }) * 10,679\end{aligned}$
Weight of the sediment

\section{Roanoke sediment core}

We collected a sediment core in a tupelo-cypress backswamp in the lower reach of the river $\left(35.85^{\circ} \mathrm{N}, 76.90^{\circ} \mathrm{W}\right.$ : Figure $\left.1 \mathrm{c}\right)$ to evaluate past patterns of vegetation and hydrologic variability. Using a vibracorer with a $7.8 \mathrm{~cm}$ diameter aluminum core barrel, we penetrated $267 \mathrm{~cm}$ of sediment; the resulting core was $170 \mathrm{~cm}$ long after compaction. After describing the core lithology, we removed 1-2 $\mathrm{cm}$ increments of sediment for pollen analysis and processed them as outlined above. The modern hydroperiod at the site is 218 days, and elevation is $0 \mathrm{~cm}$ above the mean river level. The pre-dam (pre$\mathrm{AD}$ 1950) hydroperiod for the site is estimated at 167 days, which would support bottomland hardwood forests characteristically found on low ridges and flats in the current system.

Chronology for the core was based on 14 radiocarbon dates obtained on plant macrofossils, pollen biostratigraphy, and lithostratigraphy. Conventional radiocarbon dates were converted to calibrated years before present (cal. yr BP, where present is defined as AD 1950) using the Pretoria Calibration Procedure (Stuiver et al., 1998; Talma and Vogel, 1993). Increased abundance of Ambrosia pollen to $>2 \%$ at $48 \mathrm{~cm}$ and a change from dark brown, highly organic muds of unit $\mathrm{C}$ to gray-brown to olive-greenish-gray muds of unit B (Figure 2) mark the initiation of Colonial land clearance in the Piedmont early in the eighteenth century. The change to oxidized organicrich muds/clays of unit A at $16 \mathrm{~cm}$ is correlated with completion of the John H. Kerr dam in AD 1953 (Manooch and Rulifson, 1989); a radiocarbon date of $120.7 \pm 0.4$ pMC (percent modern carbon) at $10.5 \mathrm{~cm}$ is consistent with this assignment. We used Bchron (Haslett and Parnell, 2008; Parnell et al., 2008) to generate age models for the sediment core (Figure 2); this program combines stochastic linear interpolation between points with uncertainty associated with age assignments to generate a series of chronologies.
Roanoke Core 01-10-11-4

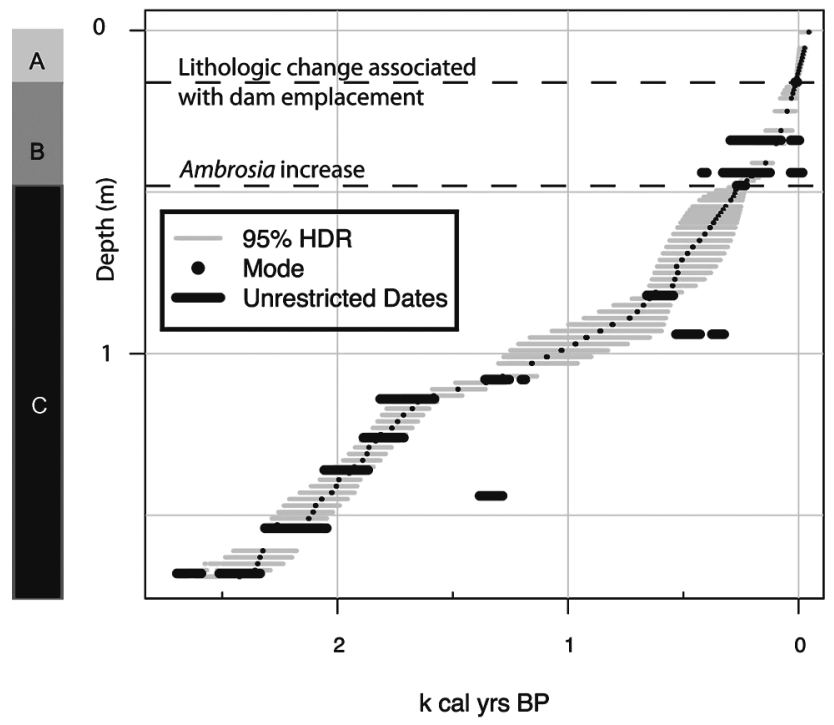

Figure 2. Lithologic zones and calendar year chronologies and for Core $0 \mathrm{I}-10-1 \mathrm{I}-4$. Lithologic zone $\mathrm{A}$ is an oxidized organic-rich mud/ clay (Munsell IOYR 5/6); zone B includes basal gray-brown mud (5Y 5/I) grading into olive greenish-gray organic-rich much/clay (5y $5 / 2$ ); zone $C$ is a dark brown, organic-rich mud (IOYR 2/I) with interspersed wood fragments. The calendar year chronology was constructed with Bchron v 2.I (Haslett and Parnell, 2008). The 95\% highest posterior density regions (HDR) indicate the uncertainty of the ages assigned to the samples between the dated depths. Thick black lines represent the calibrated radiocarbon ages. Horizontal dashed lines indicate events discussed in the text

\section{Statistical analysis of palynological data}

Statistical analysis of pollen assemblages included all arboreal taxa that comprise $>1 \%$ of pollen assemblages in at least four surface samples. Ambrosia (ragweed) pollen was excluded from percentage calculations for statistical analyses of surface samples because it responds primarily to land use rather than climate variability. Its removal from percentage calculations facilitates comparison of modern and fossil assemblages to infer past hydroperiods. Ambrosia is an early successional plant that occupies cleared sites

Table 2. Radiocarbon dates from Core $0 \mathrm{I}-10-1 \mathrm{I}-4$, collected in backswamp forest of lower Roanoke River floodplain, located on transect 38 near tree tag $35\left(35.85^{\circ} \mathrm{N}, 76.90^{\circ} \mathrm{W}\right.$, indicated by red star in Figure I)

\begin{tabular}{|c|c|c|c|c|c|c|c|}
\hline Lab no. & Depth (cm) & Material dated & Method & Conventional age (yr BP) & $\delta^{13} \mathrm{C}$ & Cal age $2 \sigma$ plus $^{\mathrm{a}}$ & Cal $2 \sigma$ minus $^{a}$ \\
\hline \multicolumn{8}{|c|}{ Core $0 I-10-1 I-4$} \\
\hline Beta 202684 & $10-11$ & wood & AMS & $120.7 \pm 0.4 p M C^{b}$ & -26.6 & & \\
\hline Beta 202685 & $34-36$ & twig & AMS & $170 \pm 40$ & -27.9 & 300 & 0 \\
\hline Beta 202686 & $44-45$ & wood & AMS & $220 \pm 40$ & -28.0 & 310 & 0 \\
\hline Beta 202687 & $72-74$ & wood & AMS & $210 \pm 40$ & -26.7 & 310 & 0 \\
\hline Beta 202688 & $82-84$ & wood & AMS & $610 \pm 40$ & -24.3 & 660 & 540 \\
\hline Beta 202689 & $94-96$ & wood & AMS & $420 \pm 40$ & -24.3 & 530 & 0 \\
\hline Beta 202690 & $100-102$ & twig & AMS & $240 \pm 40$ & -28.4 & 430 & 0 \\
\hline Beta 20269l & $108-110$ & wood & AMS & $1380 \pm 40$ & -25.6 & 1330 & 1260 \\
\hline Beta 202692 & $114-116$ & wood & AMS & $1770 \pm 40$ & -25.0 & 1810 & 1570 \\
\hline Beta 202693 & $126-128$ & wood & AMS & $1870 \pm 40$ & -26.2 & 1890 & 1710 \\
\hline Beta 202694 & $136-138$ & wood & AMS & $2000 \pm 40$ & -27.3 & 2030 & 1870 \\
\hline Beta 202695 & $144-146$ & wood & AMS & $1420 \pm 40$ & -23.1 & 1380 & 1280 \\
\hline Beta 162199 & $154-160$ & wood & Standard & $2160 \pm 60$ & -26.5 & 2330 & 1990 \\
\hline Beta 202697 & 168 & wood & AMS & $2400 \pm 40$ & -24.7 & 2710 & 2340 \\
\hline
\end{tabular}

\footnotetext{
${ }^{a}$ Calibrations are based on Stuiver and van der Plicht (1998), Stuiver et al. (1998), and Talma and Vogel (I993).

${ }^{\mathrm{b}} \mathrm{pMC}$ (percent modern carbon) indicates an age of post $0 \mathrm{BP}$ and is reported as a percentage of the modern reference standard. Such values indicate that the material was living within the last 50 years.
} 
within a year of land clearance (Bazzaz, 1974; Keever, 1983). The abundance of Ambrosia pollen in eastern US sediments increased sharply from $\leq 1 \%$ before European colonization to much higher percentages after the onset of Colonial land clearance (Brush, 1984; Willard et al., 2003). Using cluster analysis on the resulting data set, we examined relationships among different samples based on species abundance in those samples. We used averagelinkage clustering (UPGMA) with the Pearson product moment correlation coefficient and the computer program MVSP 3.1 (Kovach, 1999).

The modern analog technique (MAT) is used commonly to derive quantitative estimates of past environments from paleontological proxies (Jackson and Williams, 2004; Overpeck et al., 1985). Typically, dissimilarity coefficients are calculated between modern and fossil assemblages, and samples with dissimilarity coefficients less than a specified critical value are identified as analogs. The analogous fossil and modern assemblages are assumed to represent similar vegetational composition and, by extension, similar environmental conditions, forming the basis for quantitative paleoenvironmental reconstructions. Although spatial autocorrelation of closely spaced samples may invalidate the statistical validity of transfer functions based on such data sets (Telford and Birks, 2005, 2009), our sample design minimizes its impacts. Adjacent samples on a transect were at least $50 \mathrm{~m}$ apart and collected in different forest classes with differing hydrology; although this spatial scale is very small compared with regional- and continentalscale studies, ecotones associated with hydrologic variability occur over short distances (meters) in floodplain habitats.

We calculated dissimilarity coefficients (squared chord distance, SCD) among all modern samples and used the leave-oneout cross validation technique (Malmgren and Nordlund, 1997; Williams and Shuman, 2008) to determine the critical SCD value for the wetland data set. When hydrologically transitional sites and those in disturbed sites (i.e. drained backswamps, forest regrowth) were excluded from consideration, modern samples fall into two clear groupings: tupelo-cypress backswamps (long hydroperiods with flooding persisting into the summer) and all other BHW forests (shorter, seasonal hydroperiods). Intragroup SCD values among backswamp samples average 0.13 (SD 0.06, range $0.03-0.35, n=15$ ), whereas intergroup comparisons between backswamps and other BHW forests yield mean SCD values of 0.43 (SD 0.19, range 0.03-1.32, $n=74$ ). Bottomland hardwood forest classes span a hydrologic continuum from moderate hydroperiod forests on flats adjacent to backswamps to short-hydroperiod forests on high levees, and the resulting vegetational diversity makes it difficult to distinguish subtypes of BHW forests based solely on palynological evidence. Although the mean SCD value among all BHW forests is 0.28 (SD 0.15 , range $0.02-1.25, n=74$ ), nearly every sample has at least five analogs with $\mathrm{SCD} \leq 0.15$. We developed and tested a method to estimate hydroperiod based on the MAT. We selected a subset of 79 modern samples, eliminating those in hydrologically transitional sites. For each modern sample, we identified all analogs (SCD $\leq 0.15)$, eliminated samples with fewer than five analogs, and calculated the predicted hydroperiod as the average hydroperiod of all analogs. When actual and predicted hydroperiods were compared (Figure 3), most predictions were within 1 standard deviation of the actual hydroperiod. Estimated hydroperiods for tupelo-cypress assemblages differ strongly from all BHW assemblages, and we used this method to reconstruct past hydroperiods from downcore samples.

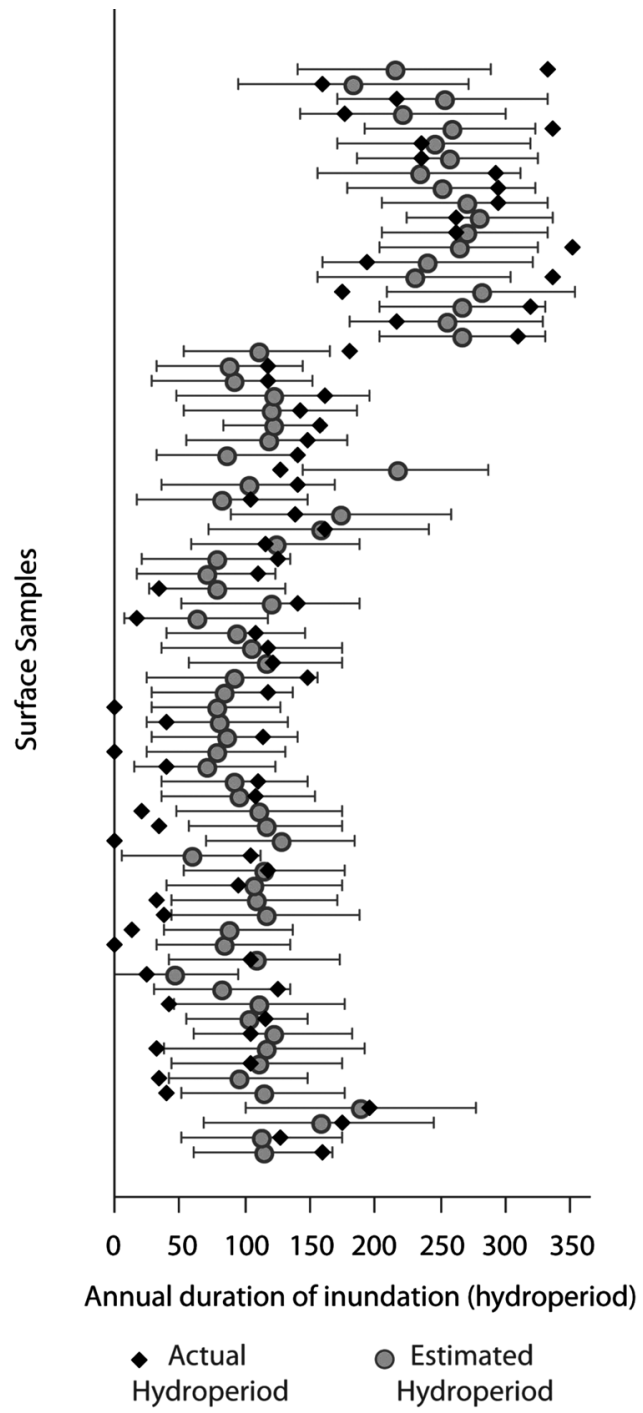

Figure 3. Comparison of predicted and actual hydroperiods in surface samples from lower Roanoke River basin, North Carolina. Circles indicate predicted hydroperiod from comparison with analogs $(S C D \leq 0.15)$. Error bars represent one standard deviation from the mean. Diamonds indicate actual hydroperiod for each site

\section{Results and discussion}

\section{Pollen assemblages from surface samples}

Four pollen species groupings are indicated by R-mode cluster analysis (Figure 4). Pinus and Juglans cluster separately from the other taxa and represent the only genera that were not observed in the study area. Although they are native to the floodplain, they were not present on any transect. Pinus, Juglans, and Carya are grouped into cluster A, which represents taxa characteristic of short median annual hydroperiods (0-7 days: Townsend, 2001) most common in upland forests or mesic BHW forests. Cluster B consists of Quercus, Fagus, Liquidambar, and Ulmus, which tolerate slightly longer annual hydroperiods ( $<50$ days) and minimal spring flooding ( $<12$ days) (Townsend, 2001); these taxa are most common in mesic BHW forests. Cluster C includes Fraxinus, Acer, and Celtis, which tolerate longer median annual hydroperiods (34-80 days) and are most common in wet BHW forests. Cluster D consists of Taxodium and Nyssa, which have median annual hydroperiods $>200$ days and are most common in tupelocypress swamp forests. 


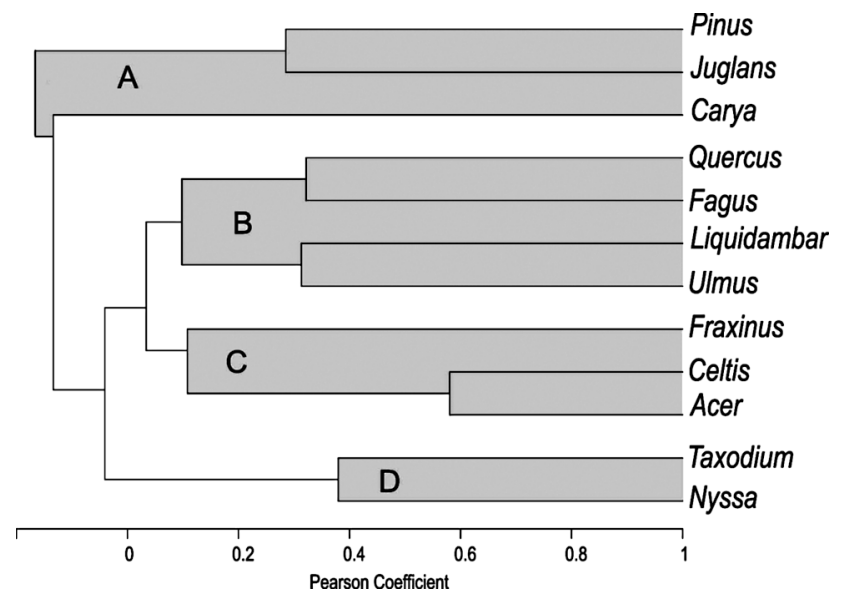

Figure 4. Dendrogram from R-mode cluster analysis (using UPGMA and Pearson correlation coefficient) of pollen assemblages from surface samples in the lower Roanoke River basin. Cluster A represents taxa characteristic of short annual hydroperiods, most commonly occurring in upland forests or mesic bottomland forests. Taxa in cluster $B$ tolerate short annual hydroperiods and minimal spring flooding, most commonly growing in mesic bottomland forests. Taxa in cluster $C$ tolerate longer annual hydroperiods and are most common in wet bottomland forests. Cluster $D$ includes taxa characteristic of long hydroperiods that are abundant in tupelo-cypress swamps

Comparison of pollen assemblages on a site-by-site basis using Q-mode cluster analysis clearly separates tupelo-cypress swamps from bottomland hardwood forests present on levees, flats, and transitional areas (Figure 5). Tupelo-cypress swamps (cluster 1) are characterized by a combined average of 33\% Nyssa and Taxodium pollen and the highest pollen concentrations of the floodplain deposits in this study (Figure 5). Backswamp sediments typically were brown organic clays, in contrast with gray-brown to dark brown silty clays, sandy clays, and sands of other landforms. Their median annual hydroperiod ranges from 150 to 300 days. Cluster 2 consists primarily of wet and mesic BHW forests that are characterized by $>20 \%$ Pinus pollen. Samples in cluster 2a include a range of landforms and forest types. Some of these sites are located in mixed swamp forests (flats) and ash-maple-boxelder bottomlands in the lower half of the river (40-90 km upstream of the river mouth), which have a median annual hydroperiod of 40-70 days. Also included in cluster 2a are sites from the middle reaches of the river that include transitions from flats to backswamps or backswamp sites near the transition with median annual hydroperiods of 60-175 days; in these, Nyssa and Taxodium each may comprise $7-12 \%$ of assemblages. Samples included in cluster $2 \mathrm{~b}$ contain $>40 \%$ Pinus pollen, typically are located $>90 \mathrm{~km}$ from the river mouth in the middle and upper reaches of the LRR floodplain, and have median annual hydroperiods of $<50$ days. Dominant forest types in cluster $2 \mathrm{~b}$ include ash-mapleboxelder bottomlands and high-levee bottomlands. Assemblages dominated by Quercus occur in cluster 3 and were produced by mesic BHW forests on levees and upland terraces with median annual hydroperiods of $<50$ days per year. Carya is abundant $(>24 \%)$ in cluster 4, which consists of wet BHW forests in transitional areas near backswamps; hydroperiods for cluster 4 range from 90 to 180 days per year.

Percent abundance of Nyssa, Taxodium, and Pinus pollen and total pollen concentration provide the primary means to discriminate between long-hydroperiod backswamps and bottomland hardwood forests (Figure 6). The highest abundance of Nyssa pollen occurs in backswamp sediments (average 19\% (14-44\%) and 87345 grains/g), followed by low levees ( $8 \%$ ). Nyssa pollen averages less than $5 \%$ (and $<7343$ grains $/ g$ ) of assemblages in medium and high levees, flats, and intermediate sites with elevations $>1 \mathrm{~m}$ above river level. Taxodium pollen is most abundant in backswamps (averaging 7\% (1-20\%) and 19889 grains/g); when reported as percent abundance, it also is common in low and medium levee deposits $(4.7-5 \%)$, but its pollen concentration is significantly lower in transitional and levee surfaces (averaging $<5500$ grains/g). Pinus pollen percent abundance is greatest in sediments from high levees, flats, and intermediate sites, in which it averages $>40 \%$ of assemblages. Lowest percentages of Pinus pollen occur in backswamps, where it averages $26 \%$. However, Pinus pollen concentrations are greatest in backswamps $(81762$ grains/g), compared with 28441 grains/g in intermediate sites and 19788 grains/g on levees. The greater concentration of these taxa in backswamps is mirrored by total pollen concentration, which is at least three times greater in backswamps than in other landforms. This pattern may reflect some combination of lower sedimentation rates in backswamps (effectively concentrating pollen), greater connectivity of backswamps with the river and fluvial transport of pollen to the site, and poorer palynomorph preservation in levees and other exposed/oxidized sediments. The uniformly high concentration of Pinus pollen across the landscape is due to its great abundance in southern mixed forests of the southeastern USA and the large quantities of wind-dispersed pollen that it produces (Delcourt et al., 1984).

\section{Paleohydrologic reconstruction from floodplain sediment core}

Pinus pollen dominates assemblages in the organic-rich muds deposited before Colonial land clearance, oscillating between extremely high (60-80\%) and lower (40-50\%) abundances throughout the sequence (Figure 7). In post-Colonial sediments, Nyssa co-dominates with Pinus, and herbaceous, weedy taxa are more common than any time prior to land clearance. Constrained cluster analysis of assemblages (CONISS: Grimm, 1992) and visual inspection of data were used to assign four pollen zones.

Pollen zone 1 (170-152 cm; 2438-2196 cal. yr BP) is dominated strongly by Pinus (58-75\%), with common fern spores and Nyssa pollen. Modern analogs for zone 1 consist almost exclusively of BHW forests (Figure 7). In pollen zone 2 (152-124 cm; $2159-1790$ cal. yr BP), Pinus pollen is less abundant (typically $38-53 \%$ ), and Taxodium pollen is subdominant (8-33\%). Nyssa pollen typically comprises $>10 \%$ of assemblages. Modern analogs consist primarily of backswamp sites, although analogs from wet BHW forests also were identified for the upper samples of zone 2. Although Pinus pollen dominates pollen zone 3 (124-40 cm; 1762-151 cal. yr BP), four subzones were identified (Figure 7). Basal subzone $3 \mathrm{a}(124-100 \mathrm{~cm} ; 1762-1151 \mathrm{cal}$. yr BP) is dominated strongly by Pinus pollen (65-90\%), and modern analogs consist entirely of BHW forests. In pollen subzone $3 \mathrm{~b}(100$ $88 \mathrm{~cm}$; 1093-754 cal. yr BP), fern spores are subdominant (16-27\%), and Nyssa and Taxodium pollen collectively exceed $10 \%$ of assemblages. Modern analogs include a mix of BHW forests and backswamp sites. Pinus pollen is strongly dominant (61-80\%) in subzone $3 \mathrm{c}(88-48 \mathrm{~cm} ; 714-260 \mathrm{cal}$. yr BP), and modern analogs consist entirely of BHW sites. Pollen subzone $3 \mathrm{~d}$ 


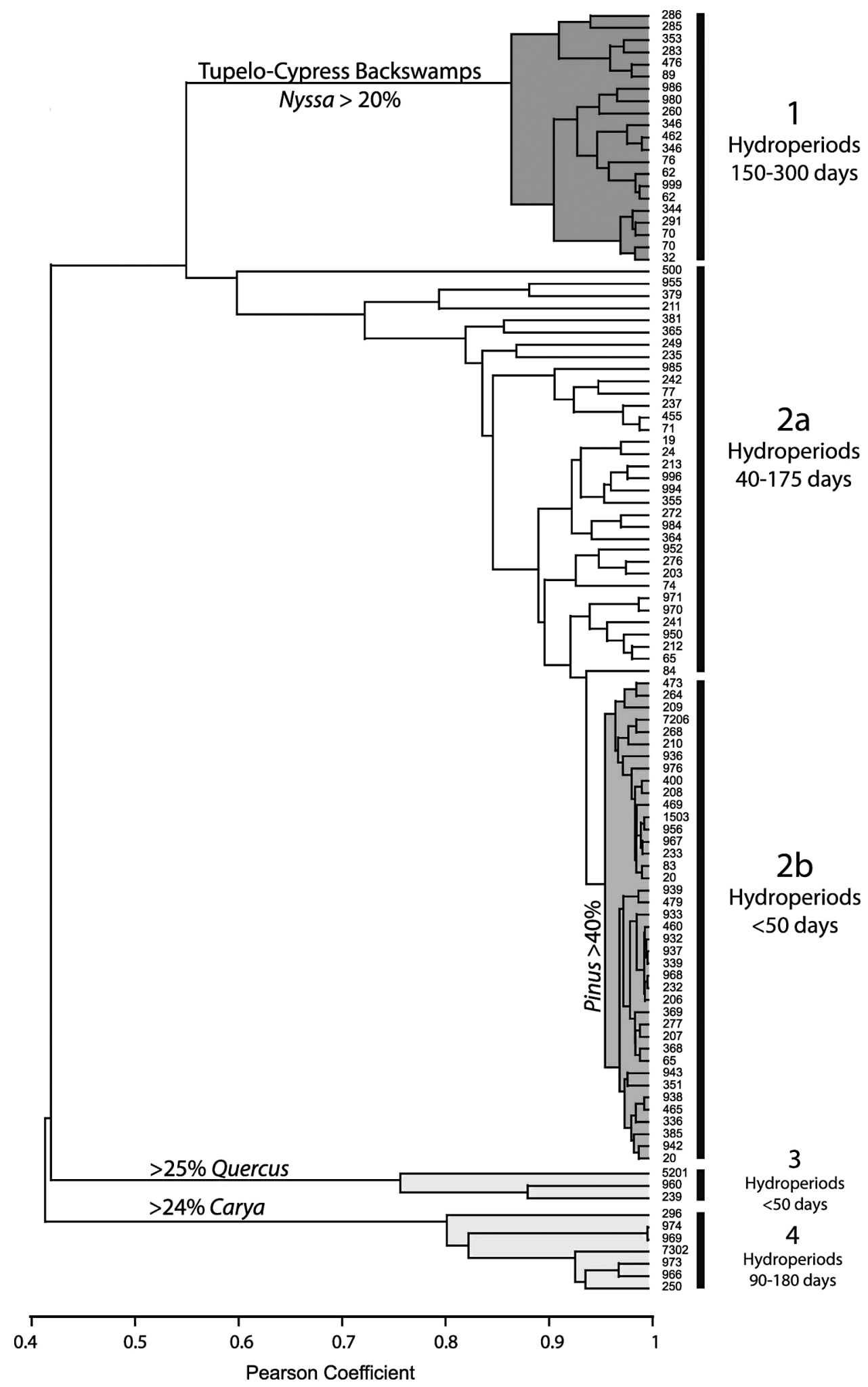

Figure 5. Dendrogram from Q-mode cluster analysis of pollen data from surface samples in the lower Roanoke River (LRR) basin. Numbers indicate the tree tag nearest each sample site. Cluster I includes samples from backswamp forests, characterized by $>20 \%$ Nyssa pollen. Cluster 2 includes samples with $>25 \%$ Pinus and $<20 \%$ Nyssa pollen. Subcluster $2 a$ includes samples located in transitional areas near backswamps or edges of backswamps, are characterized by $25-40 \%$ Pinus pollen and varying percentages of bottomland hardwood and backswamp taxa, depending on location within the floodplain. Subcluster $2 \mathrm{~b}$ consists of levee and transitional sites located in the middle and upper reaches of the LRR; these assemblages have $>40 \%$ Pinus pollen. Clusters 3 and 4 represent samples from mesic bottomland forests on levees, upland terraces, and transition zones adjacent to backswamps

(48-40 cm; 242-151 cal. yr BP) includes the first occurrence $>2 \%$ Ambrosia and more Nyssa (10-19\%). Modern analog sites include a mix of backswamp and BHW sites. Pollen zone $4(35-0 \mathrm{~cm} ; 108$ cal. yr BP to present) is co-dominated by Nyssa and Pinus pollen, and Ambrosia is abundant; its modern analogs predominantly are backswamps. 

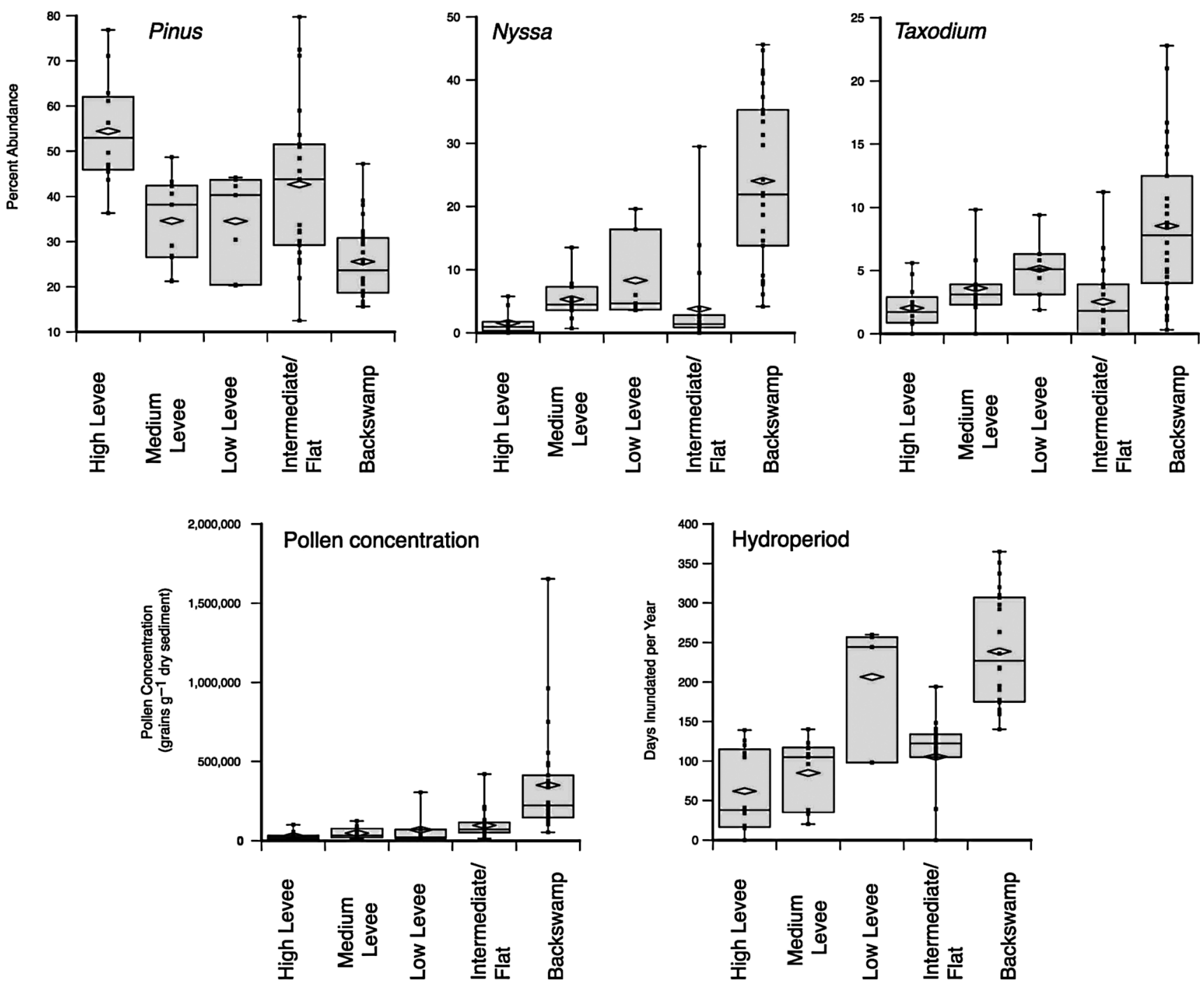

Figure 6. Tukey box and whisker plots of pollen percent abundance of diagnostic taxa, total pollen concentration, and hydroperiod in surface samples from five landforms in the lower Roanoke River basin. Points indicate individual sample abundance, and the diamond indicates the mean. The horizontal line within the box indicates median abundance for the vegetation type, and the box indicates values for the lower and upper quartile

Reconstructed hydroperiods at the site indicate centennialscale variability between dry periods (inundation $\sim 100$ days per year) and wet periods (inundation $>200$ days per year) throughout the last $\sim 2400$ years (Figure 7). Between 2400 cal. yr BP and the onset of Colonial land clearance in the early eighteenth century, dry intervals supporting short-hydroperiod bottomland hardwood forests alternated with wet intervals that supported long-hydroperiod cypress-tupelo swamps and transitional forests. Three wet intervals were identified: $\sim 2200$ to $\sim 1800$ cal. $\mathrm{yr} B P, \sim 1100$ to $\sim 750$ cal. yr BP, and $\sim 370$ cal. yr BP until Colonial land clearance. Much longer hydroperiods occurred by $\sim \mathrm{AD} 1850$, followed by significant fluctuations throughout the last 150 years. The magnitude of observed late-Holocene fluctuations in Nyssa abundance (and by extension, hydroperiod) are comparable with the differences reported between early- and late-Holocene sediments from floodplains in Georgia and North Carolina (Goman and Leigh, 2004; LaMoreaux et al., 2009).

\section{Paleoclimatic interpretations}

Long hydroperiod, tupelo-cypress swamps of the Atlantic Coastal Plain require inundation extended past the period of maximum river discharge (winter and spring) through the summer months. In the natural system, flooding throughout the summer is maintained by summer precipitation, including tropical storm systems (Gamble and Meentemeyer, 1997). Hydroperiods at the Roanoke floodplain core site fluctuated by an order of magnitude during the last 2400 years. Because no lithologic changes indicative of altered floodplain morphology exist within the unit deposited before Colonial land clearance altered floodplain geomorphology, we suggest that the observed pre-Colonial hydroperiod fluctuations resulted from sustained changes in atmospheric circulation patterns. Summer storm frequency increases when anticyclonic atmospheric patterns off the coast draw moisture both from the Gulf of Mexico and Atlantic Ocean (Curtis, 2008; Gamble and Meentemeyer, 1997). Such changes in atmospheric flow are influenced by the configuration of the jet stream and position of the Bermuda high (Diem, 2006; Liu and Fearn, 2000).

The three wet intervals observed in the Roanoke floodplain record ( $\sim 2200$ and $\sim 1800$ cal. yr BP, $\sim 1100$ to $\sim 750$ cal. yr BP, and $\sim 370$ cal. yr BP ) generally correspond to proxy records indicating periods of increased storminess in New York, Florida and Puerto Rico (Donnelly and Woodruff, 2007; Liu and Fearn, 2000; Scileppi and Donnelly, 2007) and reduced salinity in Chesapeake 


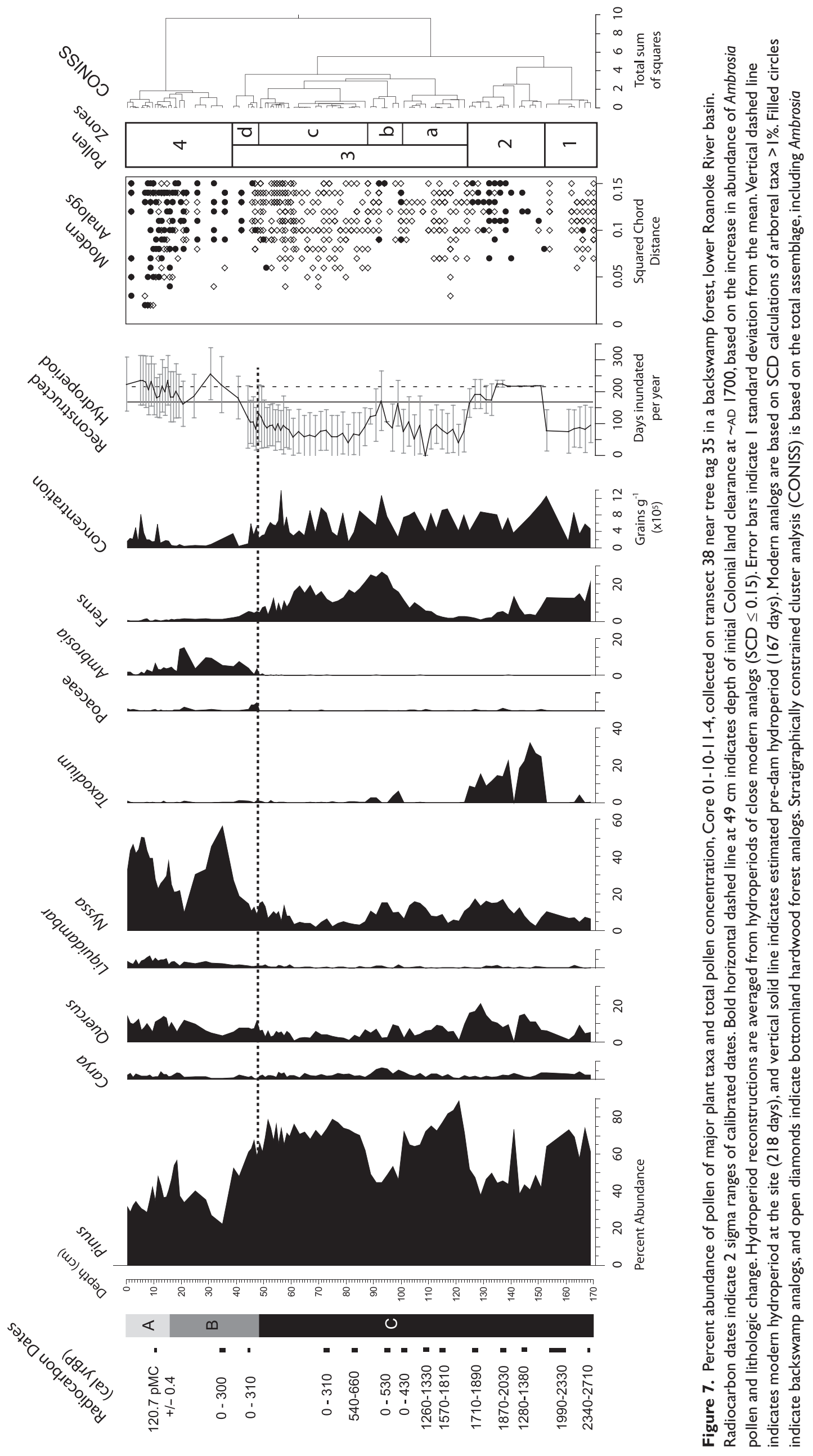


Bay (Cronin et al., 2005). A particularly robust record of increased storm frequency during the late sixteenth century is provided by archival reports from the American colonies of Spain between AD 1492 and 1825 (García-Herrera et al., 2005). These patterns have been attributed to changing modes of climate variability, including El Niño/Southern Oscillation (ENSO) and the Atlantic Multidecadal Oscillation (AMO) (Donnelly and Woodruff, 2007; Gray et al., 2004). Although these modes clearly affect precipitation and hydrology of the southeastern USA (Henderson and Vega, 1996; Enfield et al., 2001), they operate on much shorter time periods than the multicentury wet-dry trends observed in the Roanoke floodplain record, and its temporal resolution precludes further interpretation of their impacts on this site. Because such modes involve changes in atmospheric circulation patterns tied to position of the jet stream and subtropical high, the Roanoke River record supports the hypothesis that long-term fluctuations in their positions exert significant control on floodplain hydrology within the Atlantic Coastal Plain.

\section{Human impacts on Lower Roanoke River floodplain}

Two phases of anthropogenic alteration affected floodplain vegetation in the LRR basin. The first began very early in the eighteenth century, with initial European colonization of the Piedmont (http://www.usgennet.org/usa/topic/colonial/book/chap4_3.html; viewed 6 October 2009). The resulting land clearance for agriculture not only altered forest composition but greatly increased sediment load to Coastal Plain rivers, floodplains, and downstream estuaries. Increased sediment load from land clearance has deposited up to $5 \mathrm{~m}$ of post-Colonial sediment within the LRR floodplain (Hupp et al., 2009b; Townsend et al., 2004). This pattern is mirrored clearly in the Roanoke backswamp core by a three-fold decrease in pollen concentration from pre- to post-Colonial sediments. Hydroperiod at the downstream Roanoke core site also may have been influenced by post-Colonial changes in floodplain geomorphology throughout the length of the river. Increased levee height in upper reaches of the river can reduce overbank flood duration and increase channel flow velocities (Hupp, 2000), effectively increasing flow to downstream reaches of the river. The combined effects of such anthropogenic flow alterations and natural climate variability complicate attempts to determine their relative roles in forcing post-Colonial floodplain hydroperiods.

The second phase of human impacts on the LRR involved construction of a series of seven dams in the mid-twentieth century. These reduced sediment flux to the LRR, indicated by greater pollen concentrations in the Roanoke floodplain core, and altered the seasonal hydrology of the system through dam regulation schedules. The John H. Kerr dam, completed in AD 1953 has the greatest impact on the LRR because of the large storage capacity of its reservoir, Kerr Lake, and its influence on operation of the downstream dams (Manooch and Rulifson, 1989). Its operations reduced the amplitude of maximum flows by more than half, reduced the frequency of high and low flows, and increased the frequency of moderate flow (Hupp et al., 2009b). Changes in the timing and magnitude of peak flows associated with dam operations have been thought to be greater than those associated with climate variability and change (Graf, 1999; Townsend and Foster, 2002). However, data from this core indicate that natural hydrologic variability of the last 2400 years greatly exceeded that related to dam management. Pollen evidence documents sustained occurrence of conditions $50 \%$ drier than any of the last century (hydroperiods $\sim 100$ days) periodically throughout the last 2400 years. Such results indicate the need for further long-term analysis of floodplain hydrology to better assess the relative impacts of dam operations and natural climate fluctuations on floodplain ecosystems.

\section{Conclusions}

Calibration of modern floodplain pollen assemblages with source vegetation indicates that:

- Long-hydroperiod tupelo-cypress backswamp pollen assemblages differ distinctly from short-hydroperiod bottomland hardwood assemblages.

- Hydrology, forest composition, and pollen signature are closely correlated, and floodplain pollen assemblages primarily record a local pollen signature.

- Cross-validation of hydroperiod estimates among modern samples indicates that they provide a robust estimate of modern hydroperiod and can be used to infer past hydroperiod from sediment core assemblages.

- Because floodplain forests of Atlantic Coastal Plain rivers share common forest composition and geomorphology, this dataset provides a means to estimate floodplain hydrology on a regional scale.

Pollen assemblages from the Roanoke River floodplain sediment core indicate:

- Sustained, multicentury periods of wet and dry conditions alternated throughout the last 2400 years. Floodplain hydroperiods varied by an order of magnitude.

- Long-hydroperiod intervals in the LRR appear to be correlated with times of increased storm frequency and reduced estuarine salinity documented in other western Atlantic Ocean records. These patterns suggest the occurrence of periodic, sustained shifts in atmospheric circulation patterns during the late Holocene.

- Although anthropogenic alteration of the landscape and river discharge have significantly affected forest composition throughout the watershed, the resulting hydrologic changes in the study site were minor compared with those resulting from natural climate variability. Study of cores from other landforms throughout the length of the river is necessary to assess the relative influences of human activity and climate on a larger scale.

\section{Acknowledgements}

The authors gratefully acknowledge field and laboratory assistance provided by many individuals, including Tom Sheehan, Randy Richardson, Cliff Hupp, Michael Schening, Daniel Kroes, and Edward Schenk. Assistance in site location and access was provided by Jeff Horton and Sam Pearsall of The Nature Conservancy and Jean Richter of US Fish \& Wildlife Service. Robert Peet provided critical guidance on site selection, ecological insights, and constructive suggestions throughout the period of study. Radiocarbon dates were provided by Beta Analytic, Inc., Miami, Florida. The research was supported by the US Geological Survey Earth Surface Dynamics Program and NSF grant EAR GEO 0105929. We greatly appreciate critical reviews of the manuscript by Thomas Cronin, Cliff Hupp, and Robert Peet as well as two anonymous reviewers. 


\section{References}

Bazzaz FA (1974) Ecophysiology of Ambrosia artemisiifolia, a successional dominant. Ecology 55: 112-119.

Benninghoff WS (1962) Calculation of pollen and spore density in sediments by addition of exotic pollen in known quantities. Pollen et Spores 4: 332-333.

Boyles RP, Holder C and Raman S (2004) North Carolina Climate: A Summary of Climate Normals and Averages at 18 Agricultural Research Stations. North Carolina Agricultural Research Service Technical Bulletin 322.

Brush GS (1984) Patterns of recent sediment accumlation in Chesapeake Bay (Virginia-Maryland, U.S.A.) tributaries. Chemical Geology 44: 227-242.

Bunting MJ, Warner BG and Morgan CR (1998) Interpreting pollen diagrams from wetlands: Pollen representation in surface samples from Oil Well Bog, southern Ontario. Canadian Journal of Botany 76: 1780-1797.

Chmura GL, Stone PA and Ross MS (2006) Non-pollen microfossils in Everglades sediments. Review of Palaeobotany and Palynology 141: 103-119.

Cohen AD, Gage CP and Moore WS (1999) Combining organic petrography and palynology to assess anthropogenic impacts on peatlands. Part 1. An example from the northern Everglades of Florida. International Journal of Coal Geology 39: 3-45.

Conner WH and Buford MA (1998) Southern deepwater swamps. In: Messina MG and Conner WH (eds) Southern Forested Wetlands: Ecology and Management. Boca Raton FL: Lewis Publishers, 263-289.

Cronin TM, Thunnel R, Dwyer GS, Saenger C, Mann ME, Vann C et al. (2005) Multiproxy evidence of Holocene climate variability from estuarine sediments, eastern North America. Paleoceanography 20: PA4006, doi: 10.1029/2005PA001145.

Curtis S (2008) The Atlantic multidecadal oscillation and extreme daily precipitation over the US and Mexico during the hurricane season. Climate Dynamics 30: 343-351.

Delcourt PA and Delcourt HR (1984) Late Quaternary paleoclimates and biotic responses in eastern North America and the western North Atlantic Ocean. Palaeogeography, Palaeoclimatology, Palaeoecology 48: 263-284.

Delcourt PA, Delcourt HR and Webb T III (1984) Atlas of mapped distributions of dominance and modern pollen percentages for important tree taxa of eastern North America. AASP Contributions Series 14: 1-131.

Diem JE (2006) Synoptic-scale controls of summer precipitation in the southeastern United States. Journal of Climate 19: 613-621.

Donnelly JP and Woodruff JD (2007) Intense hurricane activity over the past 5,000 years controlled by El Niño and the West African Monsoon. Nature 447: 465-468.

Enfield DB, Mestas-Nuñez AM and Trimble PJ (2001) The Atlantic multidecadal oscillation and its relation to rainfall and river flows in the continental U.S. Geophysical Research Letters 28: 2077-2080.

Gamble DW and Meentemeyer VG (1997) A synoptic climatology of extreme unseasonable floods in the southeastern United States, 1950-1990. Physical Geography 18: 496-524.

García-Herrera R, Gimeno L, Ribera P and Hernández E (2005) New records of Atlantic hurricanes from Spanish documentary sources. Journal of Geophysical Research 110: D03-109.

Goman M and Leigh DS (2004) Wet early to middle Holocene conditions on the upper Coastal Plain of North Carolina, USA. Quaternary Research 61: 256-264.
Graf WL (1999) Dam nation: A geographic census of American dams and their large-scale hydrologic impacts. Water Resoures Research 35: 1305-1311.

Graf WL (2006) Downstream hydrologic and geomorphic effects of large dams on American rivers. Geomorphology 79: 336-360.

Gray ST, Graumlich LJ, Betancourt JL and Pederson GT (2004) A tree-ring based reconstruction of the Atlantic Multidecadal Oscillation since 1567 A.D. Geophysical Research Letters 31: L12205.

Grimm EC (1992) CONISS: A Fortran 77 program for stratigraphically constrained cluster analysis by the method of incremental sum of squares. Computers \& Geosciences 13: 13-35.

Haslett J and Parnell AC (2008) A simple monotone process with appliation to radiocarbon-dated depth chronologies. Journal of the Royal Statistical Society Series C. Applied Statistics 47: 399-418.

Henderson KG and Vega AJ (1996) Regional precipitation variability in the southern United States. Physical Geography 17: 93-112.

Huffman RR and Forsythe SW (1981) Bottomland hardwood forest communities and their relation to anaerobic soil conditions. In: Clark JR and Benforado J (eds) Wetlands of Bottomland Hardwoods. New York: Elsevier Scientific Publications, 187-196.

Hupp CR (2000) Hydrology, geomorphology and vegetation of Coastal Plain rivers in the south-eastern USA. Hydrological Processes 14: 2991-3010.

Hupp CR, Schenk ER, Richter JM, Peet RK and Townsend PA (2009a) Bank erosion along the regulated lower Roanoke River, North Carolina. Geological Society of America Special Paper 451: 97-108.

Hupp CR, Pierce AR and Noe GB (2009b) Floodplain geomorphic processes and environmental impacts of human alteration along Coastal Plain rivers, USA. Wetlands 29: 413-429.

Jackson ST and Williams JW (2004) Modern analogs in Quaternary paleoecology: Here today, gone yesterday, gone tomorrow? Annual Review of Earth and Planetary Sciences 32: 495-537.

Keever C (1983) A retrospective view of old-field succession after 35 years. American Midland Naturalist 110: 397-404.

Kovach WL (1999) MVSP - A MultiVariate Statistical Package for Windows. Pentraeth: Kovach Computing Services.

LaMoreaux HK, Brook GA and Knox JA (2009) Late Pleistocene and Holocene environments of the Southeastern United States from the stratigraphy and pollen content of a peat deposit on the Georgia Coastal Plain. Palaeogeography, Palaeoclimatology, Palaeoecology 280: 300-312.

Liu K-B and Fearn ML (2000) Reconstruction of prehistoric landfall frequencies of catastrophic hurricanes in northwestern Florida from lake sediment records. Quaternary Research 54: 238-245.

Maher LJ Jr (1981) Statistics for microfossil concentration measurements employing samples spiked with marker grains. Review of Palaeobotany and Palynology 32: 153-191.

Malmgren BA and Nordlund U (1997) Application of artificial neural networks to paleoceanographic data. Palaeogeography, Palaeoclimatology, Palaeoecology 136: 359-373.

Manooch CS III and Rulifson RA (1989) Roanoke River Water Flow Committee Report. A Recommended Water Flow Regime for the Roanoke River, North Carolina, to Benefit Anadromous Striped Bass and Other Below-dam Resources and Users. NOAA Technical Memorandum.

Mitsch WJ and Gosselink JG (2000) Wetlands. New York: Van Nostrand Reinhold.

Overpeck JT, Webb T III and Prentice IC (1985) Quantitative interpretation of fossil pollen spectra: Dissimilarity coefficients and the method of modern analogs. Quaternary Research 23: 87-108. 
Parnell AC, Haslett J, Allen JRM, Buck CE and Huntley B (2008) A flexible approach to assessing synchroneity of past events using Bayesian reconstructions of sedimentation history. Quaternary Science Reviews 27: 1872-1885.

Pearsall SH, McCrodden BJ and Townsend PA (2005) Adaptive management of flows in the Lower Roanoke River, North Carolina, USA. Environmental Management 35: 353-367.

Pederson DC, Peteet DM, Kurdyla D and Guilderson T (2005) Medieval warming, Little Ice Age, and European impact on the environment during the last millennium in the lower Hudson Valley, New York, USA. Quaternary Research 63: 238-249.

Peet RK, Wentworth TR and White PS (1998) A flexible, multipurpose method for recording vegetation composition and structure. Castanea 63: 262-274.

Putnam JA, Furnival GM and McKnight JS (1960) Management and inventory of southern hardwoods. U.S. Department of Agriculture Agriculture Handbook 181, 108.

Rice SK and Peet RK (1997) Vegetation of the Lower Roanoke River Floodplain. Durham NC: The Nature Conservancy.

Scileppi E and Donnelly JP (2007) Sedimentary evidence of hurricane strikes in western Long Island, New York. Geochemistry, Geophysics, Geosystems 8: 1-25.

Stockmarr J (1971) Tablets with spores used in absolute pollen analysis. Pollen et Spores 13: 615-621.

Stockmarr J (1973) Determination of spore concentration with an electronic particle counter. Aarbog - Danmarks Geologiske Undersoegelse 1873: 87-89.

Stuiver M and van der Plicht H (1998) Editorial comment. Radiocarbon 40: xii-xiii.

Stuiver M, Reimer PJ, Bard E, Beck JW, Burr GS, Hughen KA et al. (1998) INTCAL98 radiocarbon age calibration, 24,000-0 cal BP. Radiocarbon 40: 1041-1083.

Talma AS and Vogel JC (1993) A simplified approach to calibrating C14 dates. Radiocarbon 35: 317-322.

Telford RJ and Birks HJB (2005) The secret assumption of transfer functions: Problems with spatial autocorrelation in evaluating model performance. Quaternary Science Reviews 24: 2173-2179.

Telford RJ and Birks HJB (2009) Evaluation of transfer functions in spatially structured environments. Quaternary Science Reviews 28: 1309-1316.

Townsend PA (2001) Relationships between vegetation patterns and hydroperiod on the Roanoke River floodplain, North Carolina. Plant Ecology 156: 43-58.

Townsend PA and Foster JR (2002) A synthetic aperture radarbased model to assess historical changes in lowland floodplain hydroperiod. Water Resources Research 38(7): 1115 doi: 10.1029/2001WR001046.
Townsend PA and Walsh SJ (1998) Modeling floodplain inundation using an integrated GIS with radar and optical remote sensing. Geomorphology 21: 295-312.

Townsend PA, Brown RA, Willard DA, Hupp CR, Peet RK and Pearsall SH (2004) Ecosystem change at multiple temporal and spatial scales: Linking hydrology, geomorphology and ecology on the Roanoke River floodplain, North Carolina. Geological Society of America Abstracts with Programs 36: 141.

US Department of Health, Education and Welfare (1962) Investigation of the Lower Roanoke River Basin, Virginia and North Carolina: Effects of the John H. Kerr Project on Water Quality. U.S. Department of Health, Education, and Welfare Report 903R62101, 1-173.

Watts WA (1979) Late Quaternary vegetation of Central Appalachia and the New Jersey Coastal Plain. Ecological Monographs 49: 427-469.

Watts WA (1980) Late-Quaternary vegetation history at White Pond on the Inner Coastal Plain of South Carolina. Quaternary Research 13: 187-199.

Watts WA, Grimm EC and Hussey TC (1996) Mid-Holocene forest history of Florida and the Coastal Plain of Georgia and South Carolina. In: Sassaman KE and Anderson DG (eds) Archaeology of the Mid-Holocene Southeast. Gainesville: University Press of Florida, 28-38.

Wharton CH, Kitchens WM, Pendleton EC and Sipe TW (1982) The Ecology of Bottomland Hardwood Swamps of the Southeast: A Community Profile. U.S. Fish and Wildlife Service.

Whitehead DR (1972) Development and environmental history of the Dismal Swamp. Ecological Monographs 42: 301-315.

Whitmore J, Gajewski K, Sawada M, Williams JW, Shuman B, Bartlein PJ et al. (2005) Modern pollen data from North America and Greenland for multi-scale paleoenvironmental applications. Quaternary Science Reviews 24: 1828-1848.

Willard DA, Cronin TM and Verardo S (2003) Late-Holocene climate and ecosystem history from Chesapeake Bay sediment cores, USA. The Holocene 13: 201-214.

Willard DA, Bernhardt CE, Korejwo DA and Meyers SR (2005) Impact of millennial-scale Holocene climate variability on eastern North American terrestrial ecosystems: Pollen-based climatic reconstruction. Global and Planetary Change 47: 17-35.

Willard DA, Bernhardt CE, Holmes CW, Landacre B and Marot M (2006) Response of Everglades tree islands to environmental change. Ecological Monographs 76: 565-583.

Williams JW and Shuman B (2008) Obtaining accurate and precise environmental reconstructions from the modern analog technique and North American surface pollen dataset. Quaternary Science Reviews 27: 669-687. 